\title{
TRUST AND BUSINESS TRANSACTION
}

\author{
Pheni Chalid \\ State Islamic University (UIN) SyarifHidayatullah Jakarta \\ pheni.chalid@uinjkt.ac.id
}

\begin{abstract}
Aim of this paper is to explore the root and role of trust within business cycle and transaction. Any business and social transactions contain complexity and are built on the basis of trust and rational calculation. Fluctuation of price of any commodities and level of their selling products are determined by the degree of consumers' trust. Lessons learned from the field teaches that the trust easy to be gone and hard to be re-treated. Keeping trust is very important since any transactions tend to face business failure but existing trust in business commitment will diminish the risk of losing. It is reason why businessmen rely on not only rational calculation but also on emotional, cultural and ethnicity based of trust.If not, it will engender serious risk.
\end{abstract}

Keywords: Trust;Business Transaction;Benefit

\begin{abstract}
Abstrak
Tulisan ini dimaksudkan untuk menemukan akar dan peran kepercayaan dalam siklus bisnis dan transaksi. Aneka transaksi bisnis dan sosial yang dilakukan tidak selalu sederhana prosesnya dan pasti dibangun atas dasar kepercayaan dan perhitungan yang rasional. Karena fluktuasi harga dan tingkat penjualan ditentukan oleh tingkat kepercayaan konsumen. Pelajaran yang didapat dari lapangan menunjukkan bahwa kepercayaan sangat mudah hilang dan jika cedera sangat sulit untuk pulih. kepercayaan sangat penting dipupuk karena tiap bisnis menghadang risiko, namun karena adanya kepercayaan maka risiko dapat dihindari. Tidak heran usahawan melakukan berbagai upaya untuk membangun kepercayaantidak hanya dalam bentuk formal tapi juga berdasarkan hubungan emosional, kedekatan budaya dan hubungan etnik. Jika tidak, maka kelangsungan bisnisnya akan sangat terancam.
\end{abstract}

Kata Kunci: Kepercayaan; Business Transaction; Benefit

Received: May 20, 2016; Revised: August 25, 2016; Approved: September 9, 2016 


\section{INTRODUCTION}

This paper is aimed to explore the role of trust within business cycle and economic transaction. It is started from an adagio that doing Business is always started from and always run with trust. No any business commitment and transactions can be done without existence of trust. The trust is up and down but its growing is in line to the intensity and quality of interaction among actors. The trust is built always going through interaction and using rational calculation for profit, by hindering any losses.

Economic transaction is neutral in its character means, there is an intention simply to meet the needs, and it is based on loss and profit calculation. But, the most fundamental relation in searching for economic motives are determined and controlled by the trust. It is almost not possible for someone to build any economic commitments without existing trust since it will engender a serious risk. Economic transaction and social interaction are unconsciously motivated by trust. And, fluctuation of socioeconomic exchange in society such as reciprocity is also much more controlled by the presence or absence of trust. Therefore, the trust is becomes a kern of any business transaction even in the modern mode of transaction.

Fluctuation of price for any commodities, level of their selling products and maintaining asa loyal consumers are much more determined by the degree of consumers' trust. Lessons learned from different experiences from the field teaches us that the trust easy to be broken but hard to be normalized. Whichever the tendency of the trust is, it directly influences up and down the value of transaction such as selling product. Any transactions tend to face business failure but existing trust in business commitment will diminish the risk of losing.

Realizing how imnporrtant the trust in running is, businessmen try to build the trust and seek any possible way to get and establish trust not only producing high quality products, award loyal present to the cosumers, and offering after sale service but also using socail capital, emotional relationship and ethnicity. It is reasonwhy businessmen rely on emotional, cultural and ethnic based relationship of trust are implemented during running of business. If they fail to catch the social trust, it will engender. Trust plays important role in any business transactions but its topic within economic discipline has not become a special issue for discussion so far. Only, some works of social economist such Granoveter, Smelser, Heilborn, and Furlongintroduced 
the trust ontheir works. I find that trust has become a key issue in economic transaction, game theory and economic sociology.

Trust is a normal term to describe the degree 'social beleive' which is embedded to the products, actors, and institution. But it is really sensitive issue in doing busines. By keeping strong trust wil get direct and indirect benefit as well. On the opposite if one product is known not good in quality then the consumers will avoid automatically to buy the product or services. Trust can be applied to persons, groups and organizations because all three entities make trust decisions and exhibit the measurable actions that follow from such decisions (Li:20I5).

Trust in the modern company is represented by formal agreement wherein any aspects of administration, financial, procedures and rights and obligations of actors involved are stated in trhe formal contract. As mentionned that any business are started, with, and always with existing trust. Thus, before the contract is initiated and signed will be proceded by trust. To assure well running of company, the trust plays important role in company operation.

In business competition, issue of trust also considererd a very strategic way to weaken the conpetitors. Some times, other competitiors practice black campaign and 'stigmatize' competittor's products to win in the competion. Whenever the consumers loss their trust to a prodduct, they will never come and buy again.

Biscuit Roma case in nineties can be an example of lossing trust. careless of putting dangereous chemical substanace in the process of Biscuit product which endangers of health. More than two years for Biscuit Roma to get back consumer trust.Other examples are loosing consumer trust to meat ball, chicken, meat, and their derivative products because putting poisonous materila in the product.

In the economic sociology, the issue of trust is introduced by Granovetter and Swedberg (1992)and followed by Smelser and Swedberg (1994) in their Sociology of Economic books and also on theirhandbook of Economic Sociology. While Warren tried to link the trust to political issues in his book Democracy and Trust (1999). The only book was particularly written on trust in Indonesian language (Pheni, 2009) and English version (Pheni, 20II). There is a limited discussion and publication so far on the trust whichprovides a wide room to be exercised. 
Trust and Business Transaction

Pheni Chalid

\section{METHOD}

Main sources for discussion on this paper are derived from cross issues analysis on the topic of the role of trust in economic transaction firstly introduced by some well-known writers on the trust in economic sociology, mainly done by Granoveter, Smelser, and Swedberg.First step is mapping the role of trust in running business to look for its importance. Then, going more to describe the interconnected notion of trust in economic aspects. Inspired by those writers, this paper is expanded to trust implications in economic transaction in the market practices. Then, analysis is to justify that trust as social capital is not only existence in traditional mode of transaction but also true existence in the modern free market practices since there is a common rule in the trust that the more the consumers trust a product is, the more likely they would buy it. The more the trust of consumers to the transaction processes and procedures is, the more likely they would come and buy again. To be rooted by the facts and to strengthen the notion of the role of trust in business, before coming to conclusion, some cases are discussed on how importance the role and implication of trust in up and down of transaction.

\section{RESULT AND DISCUSSION}

\section{Trust in Economic Perspective}

In the perspective of neoclassical economic paradigm, in the perfect free market the trust is not needed. It is because of the perfect market is fulfilled by the anonymous market actors, buyers and sellers who meet in a short time to exchange standardized goods. All economic actors in a perfect market competition try to maximize their welfare, but not including the pursuit of self-interest with the adverse action. Although there are opportunities for dishonest acts because of the urgent need of market information, they try to make a trust issue absent from any deal because the economic system works in a transparent manner already.

The idea of free market comes from the Adam Smith that the people in the same trade can freely meet and the conversation among them usually ends up in a conspiracy to the public to create a high price (Furlong 1996:4). The issue is, market in the real realm is not perfect and will always open the opportunities for dishonest behavior. The idea of classical economy on no existing trust in the free market is 
acceptable if the transaction is only occurring at once and at one spot. But, the trust also is also treated for the goods, services and trade mechanism where the transaction can be occurred anytime and anywhere.

The economic exchange provides a profit opportunity. For profit, the opportunistic actors will do anything, including providing wrong information to the others. In addition, the uncertainty in the market also leads to the ambiguous information. The crucial point is in the situation that each economic actor still has the same opportunity. To identify from whom the opportunity is adequately obtained and from whom this opportunity cannot be obtained will need some cost. Therefore, the existence of the trust to the actors, goods, services and trade mechanism become the element of economic efficiency.

Trust, as social capital in the industrial economy,drives such necessity to work together. As company has to build trust relationship among individual members because they operate according to same ethical norms, thus it will be able to reduce both social and economic cost. Conversely, in a distrust society, cooperation among the member can only be done by regulation and the formal rule system. It will require tough negotiations process, approval of procedural mechanisms, litigation and enforcement. These legal devices are explicitly can replace the trust, but it leads another charge of "transaction costs" (Granoveter, 1995:28).

Rational economic player, at certain level, is urged to develop a smart strategy to anticipate the deviant behaviors in the economy. Contract, as a legal mechanism that regulates the cooperative relations is crucial in overcoming economic problems associated with the trust (Damsar, 1997:41-42) On this basis, economists argue that this existence contract is made on the basis of rational calculation and it has replaced the trust in economic cooperation relation, which affects the formation of cultural independent association.

Contract in legal and economic aspects, can glue the people who do not know each other in a partnership without any prior claim to believe. Trust is not able to replace the function and position of the contract as a legal institution. But, the contract will be more efficient with the trust, so it can minimize the transaction costs, claims and complaints. The contracts that are formulated based on distrust assuming that a business associate can do cheating any time, therefore, in the decision making process 
will consider all possibilities to ensure that there would be no advantages gained by illegal means. As a result the contract is very detailed and contains all the detail and definitive obligations of actors involved.

Kenneth Arrow in Fukuyama (1992:15I-152) has argued that trust has very important pragmatic values. The trust is the lubricant of social systems that work efficiently to solve many problems through a fair level of honesty. Unfortunately, trust is not a commodity that can be easily obtained. The trust and other similar values, such as honesty and truth-telling is what is the economist called as economic "externalities".Degree of trust becomes a determinant factor in the continuation of business and any social relationship. If the trust is high, the business will run well and relationship will remain stable. But, on the contrary, if the trust is diminished, then the business will go bankrupt and relationship will fade away.

Trust is sometimes understood as subjective entity; which means it depends on personal experiences, which are different from one to another. Even though it seems to be subjective, but it does not mean that rationality is left out. Almost in every economic and social action one considers the possibility of the risk. Take friendship for example, this type of relationship seems to be built voluntarily, but it is not like that at all. Friendship can be used as an illustration of social relationship with full rational calculation that is to get fortune and avoid unnecessary problem and cost.

Trust in economy is notgiven but its growth depends on the process of economic and social interaction. Its level is determined by how effective the interaction is and how positive the impression obtained from the existing relationship. However, one thing, which cannot be denied is that trust is the result of intensive social interaction and it grows alongside with rational calculation.

Rational considerations accompanying trust will the level of strength of trust which has been developed. This statement makes the discourse of trust becomes complex and problematic. The rationality according to Weber is a rule about common logic which becomes the reference in which aspect of subjective behavior can be assessed objectively. For example, a painting by a maestro an international auction room that is sold at a very fanciful price to a billionaire. For common people, the action of buying an incomprehensible painting is irrational and is considered wasting money. But for the owner, a painting of a maestro makes a good investment. 
From the illustration, we can conclude that trust is very valuable. The higher the trust, the more valuable the relationship, which eventually leads to higher economic advantage. We may be astonished to learn the price for Picasso's or Rembrant's paintings which can reach billions. Perhaps it is difficult for another auction houses to compete with Christie's that has the capability to sell luxurious, rare, and one of only piece of arts because people has put their trust in it.

Everyone is the active player in trust building; his individual action will determine his trustworthiness. The degree and the fluctuation of trust is performed and determined by the actor. In turn, trust is applied to actor in doing business, the productsconsisting of any goods produced and services offered, and the last is the mechanism established and system createdby the people.

We are now going to explore more about trust beyond its use in material transaction. Let's start from Hobbes' logic that believe in the world is aimed to look for material satisfaction which becomes the one and only source to make life meaningful.Recent world, materialism becomes the main spirit in any influential ideologies in the world. The materialism has given considerable impact, as stated by Marx, that idea of human being is the expression of material condition. From the materialistic rationality, the embeddedness of the trust in the society cannot be separated from the dynamic of materialistic reality. It is the reason why trust can be measured and oriented to satisfy material necessity.

Multi facet relationships of rationality with various behaviors make them very complex. Also, trust will follow the way of thinking, culture and ideology in society.According to Weber, the development of modern in the western society is related to with the development of rationality. This development is reflected in daily individual economic action and in the structure of social organization. It is also expressed in the evolution of western music. There are existing standard and structure to what is said good music and how to express the perfect feeling is. Although music is often seen as an emotional language, Weber shows that the development of music also follows rationalization tendency which permeates to the development of modern western civilization (Weber, in Johnson, 1988:207). Weber's argumentation can explain the phenomenon why western countries become dominant in almost all living 
sectors, whereas the eastern countries and other groups of society stay in the subordination of the west and its culture.

The domination and hegemony of western countries remains cannot be subjugated until this time. The high level of trust in technology, product and skill of western countries is supported by wealth and well-being of their social, economic, and politic affairs. Pavlov, a Russian clinical psychologist, views that trust grows because it is conditioned. Therefore, industrial countries with strong currency, investment, and high gross national product can be said that they are earning high level of the trust. On the other hand, countries with low rate exchange, income, and investment are earning low trust. It is safe to say that the difference of the level of trust happens because it is conditioned. It means, people have more trust to rich, well organized, with good performance, having experience and high moral conduct and professionalism or skill. All these characteristics, more or less, can be applied to indicate whether such country is in the high trust or not.

\section{The Problems of Trust in Market Economy}

The market economy that usually focuses on the calculation of profit or loss has encouraged the growth of trust among the market players. Trust that emerges in the market consists of the trust that is intertwined among market actors and consumers. The consumers trust is a priority in the market; something for which producers and traders always compete. It is also the reason why almost all producers claim that their products are the best in quality because such claim can attract consumers' attention. By doing so, it is expected that the claim would be implanted into the mind of the consumers, so the brand would remain in consumers' memory. If consumers trust in it, they may keep buying and they become loyal consumer.

Active economic actors, i.e. producer and trader have special relationship qualities. Luhmann (1998) specifically states that trust would only appear under certain circumstances where the possibility of loss was greater than the expected profit. The reason to take the risk is based on self-assurance that the partner will not act opportunistic.In a modern society where social relationship moves beyond territory, trust is also broaden its reach beyond primordial sphere. Friendship and university alumni often become the basis to establish networking. Friendship that is developed 
from neighborhood, school, or similar interest is a kind of relationship that is naturally formed because they are inclined to do so.

People who have similar interest, career and hobby may establish relationship without considering their place of origin or their descendants. This organic relationship is enabling them to get to know each other, not just their personality but also their capacity, especially when it is related to economic potentials. The trust, which is established between individual and social may change into economic relation, getting mutual benefit. However, without trust, production and distribution costs that have to be bore would be even greater. If trust exists, production flow will be more efficient and it can control itself without routine monitoring. Trust works like an internal control mechanism. There are so many companies depending on supplying partners and relations built in based on social relationships.

A closer social relationship could be categorized into close friends, family members and similar hobby and ethnic group. And, more distant relationship can be found in a relationship such as classmate or neighbor. Both social bonds have a potential to alter into an economic relationship. Notwithstanding, family members usually have better access to information and be prioritized in career movement. Trust development is not demostrating trusworthynes but also enggaging in effective communication in times of change and conflict (Chang:2016)

Social bonds often determined by the pattern of residential movement, control to particular commodity, and domination of new areas and economic zone. In informal economy, it could be seen how friendship, place of origin, and ethnicity influence the pattern of migration, destination area, sold commodity and control in particular location. In traditional market, the trade of several commodities is highly influenced by the trader's social network. This social bond is the early step of establishing networking. The networking which has been formed will continually function as the forum for information sharing and business reference as well in absorbing migration and urban flow according to what they need and what available in labor market is.

Modern market more or less practice similar mechanism. Big companies will only employ staff whose trust have been proven good or who has established emotional bond when it comes to company strategy and highly confidential corporate 
affairs. In business world, we may meet some trusted employees who have important role in the company because they have close relationship to the prominent figures in the company although they might be not playing an important role in production. But these people are particularly important for their counsel on company policies and other urgent matters in the company. This kind of mechanism is usually maintained to keep company's confidentiality and to ensure the flow of sensible information.

Network is formed and bounded informally by trust. This informal relationship is frequently practiced to fulfill the need of formal organization. Work opportunity can be accessed easier by those who are inside the network. Meanwhile, priority will be given only to those who are close to the inner circle, provided their capacities are fit for the required skills. In case of employee recruitment, trust does not merely assign closeness as the main requirement because at the same time, it also requires an adequate social capital for the candidates. Hence, there are many companies with modern working standard recruit employee based on the existing social references. A reference is a way to prove the degree of the prevailing trust in a candidate through interconnection relationship, which has a certain degree of values. It is meant to reduce possible risk that might arise in the future.

By carrying out this kind of recruitment pattern, a company has the advantage of reducing the recruitment cost and can guarantee the quality and control of the employee hired through the third party. It is expected that the new employee will adjust with work environment and system in the company more quickly. Another advantage is that there is a better chance for the recruited individuals to work conscientiously with honesty, because they feel they owe something to the employer and are being observed by the person(s) who gives those references. It is undeniable that trust in traditional sense is widely applied in the modern company.

Another type of networking formed by trust is supply chain mechanism. The relationship between producers and suppliers is considered very fragile. If a supplier breaks agreement by sending no raw materials, the goods cannot be produced and the company will face tremendous loss. The risk would even be bigger if the traded is soft commodity that is delicate by nature. Fresh meat, fish and vegetable are included in this kind of commodity; if they are not sold immediately their quality will decrease consistently. Because the nature of this product, some suppliers prefer the traders 
who are able to sell in large quantity. The mechanism is also applied to the traders who choose suppliers who can guarantee supplied commodity in timely manner

Modern production companies also emphasize the trust mechanism. Production stages that are directly related to supply and distribution are carried out through social relations. The distribution of products to the consumers in the markets also utilize social approaches, namely by giving quality assurance, displaying the products in the neat, well-designed shelves, aesthetic packaging, These efforts show that convincing products and the touch of taste serve as social comfort that relies on trust, and it contributes to the process of economic transaction.

\section{Benefits of Trust}

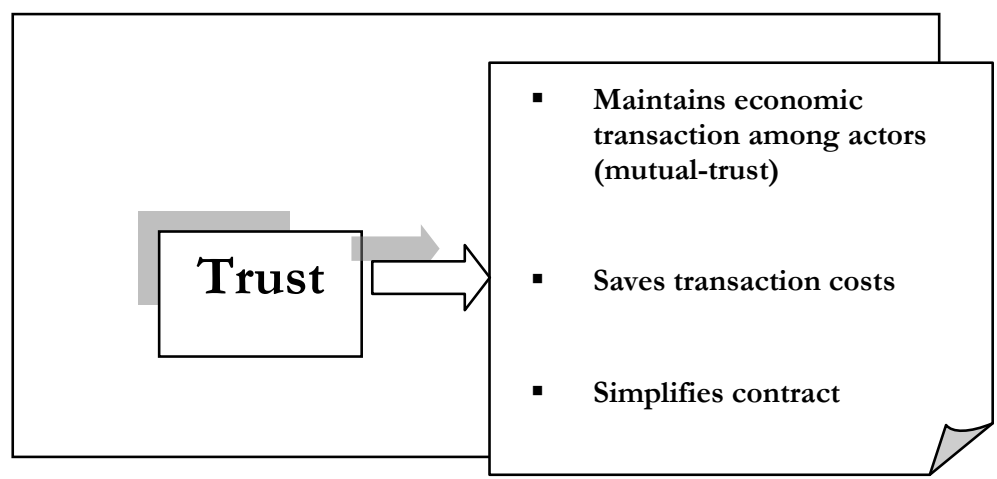

Source: Pheni Chalid, 2005

There are many trading transactions today, particularly in commodity chainsupply that still relies on primordial relationship. Ethnicity as a traditional bond is the main key of goods circulation and service provided in the market. Traditional market is characterized by sliding price system and haggling over price which resulted in low price is dominated by primordial relationship which is assumed more trust since their own ethnic is more trusted than other ethnicities. Using the mother tongue of the trader, for example, is one way to have a better price.

The transactions are more likely to occur to the people who have kinship relation, the same place of origin and ethnicity. Minang traders who immigrate to the big cities in Indonesia, for example, will help their relatives to find a location where they are can sell their goods. Or, the Sundanese vegetables traders, who sell their product in Klender Market, Jakarta, usually have the ties of kinship with the suppliers in 
Bogor, West Java. The similar case also occurs in the biggest electronic market in Glodok, Jakarta, where very dominating traders are Chinese with international chain between producers and suppliers from similar ethnicity. The suppliers and the traders are unified by ethnic identities and cultural attributes. In the case of East Asia, ethnicity makes the strongest bond in developing business because it is easily recognized and it does not any changes for the entire life.

The control over a territory and access to commodity from the first hand distributor is considered to be the determining point of dominations in commodity and market expansion. By doing so, the traders will offer a competitive price in the market. Every competition in the market is an embedded mechanism to create balance and price rationality. Until today, traders still expect to dominate the commodity to set the price. To achieve this, strong consolidation among market players and networking are necessary. In this stage trust, again, plays an important role.

The lack of confidence towards the working partner to win the highest level of competition will force one to look for a more trusted and familiar partner. Furthermore, the search for a more trustworthy partner is also originated from uncertainty in macroeconomic tendency that has been putting business in high risk. The problem of trust lies in the utilization of social relation and network to gain economic benefits, even though the relation will be bound by formal rules as the business goes on. A work in business that is started with social relation might pose some risks, but at the same time it can be advantageous.

\section{Trust and Transaction Benefit}

A commodity can be considered valuable when it has a price to exchange. Objective price appraisal can be done when the product is offered in the market. At that time, the commodity would receive some reviews from the market players and consumers. The commodities that are quickly absorbed by the market reflect the level of consumers' trust. The more the product earns the trust, the more people would demand it.The development of consumption that has reached the level of high consumption has encouraged the expansion of manufacture industry that is aimed to meet the consumers demand and taste. Consumption is no longer seen as individual and group needs, but more than that, how certain commodities become the needs of the society. In this way, the society has to be convinced that the offered product 
somewhat fits the consumers' expectation. Winning the trust of the consumers is the goal of every proprietor and trader.

The process for trust to be embodied in business requires certain period of time. In the early stage, a company might face difficulties to move from low trust to high trust relationship with the suppliers. After being successful in the first stage, the company still has to struggle to improve their level of competitiveness among companies of similar business. All these competitions will be won if consumers trust have already established not only in the product but also in company. Of course, "the company will doo any effort to build consumer trust and convert consumer trust into value and lolyalty to the certain products in relational exchanage (Sirdesmukh:2002).

A note must be taken that low trust, according to Fukuyama's (1995) perspective, is the trust that is given only to the people who are primordially bounded such as kinship, place of origin or ethnicity. Meanwhile, high trust is the trust given to people outside the primordial group. Trust is equally agreed by formalizing agreement it in a contract that covers the definition of work and teamwork, work mechanism, sanction, and so forth. However, although the contract had been formalized and put into action, trust still provides a fundamental mechanism upon which the contract is based.Trust in the recent economic advancement with massive production is affixed upon three aspects: trust in personal or groups, product and mechanism. Modern companies are able to achieve these three aspects of trust at once. It is no wonder if the modern companies are also able to improve bargaining position, remuneration, market, and commodity domination. Even in larger scale, a multinational company has the capability to influence market economy system and collect profit in an extremely huge amount of money.

\section{Some Lessons}

Economic trustin a person or group doing business can be viewed from how someone obtains strategic bargaining positions in economic interaction. Subjective judgment to an individual that is valued by a large number of people becomes an objective judgment. For example, Indonesian people tend to entrust expatriates more with a certain position in a company, as if only expatriates that are capable of doing the job. As a consequence, the company has to pay the salary 4 to 10 times higher than 
domestic expert. Another example is how the Chineseare able to build trust in trading, which makes most people choose to do business with them.Meanwhile, all producers have put their efforts to earn more trust from the consumers. The more the consumers trust a product is, the more likely they would buy it. The more the trust consumers to the transaction processes and procedures is, the more likely they would come again. For this reason, trust in the market system is arranged in such a way so the information is spread to as many people as possible at various levels of society. We know that several awards are provided to a product that is deemed reliable by the consumers such as Super-brand Award. By including the label of the award on the packaging, the notion that the product is the most reliable can be spread out, so that sale turnover would increase dramatically. The company that conducts the survey about is also betting on their reputation. If the company or the institution is not reliable, then the award will not bring any benefit.

Trust in economic mechanism has a potential to double the profit. The bank mechanism is the most representative example of this case. People save their money in the bank because they count on the system; an all they have as the assurance of the safety of their money is a small book that tells them the amount of money in their account. Without trust, it is not possible for people to adhere to the bank mechanism.

Similar phenomenon is seen in polling centers, where an announcement of the winner of the general election is disclosed only few hours after voting. Those institutions compete against each other to provide the most accurate calculation based on sampling method. Meanwhile, official calculation is only announced by the general election committee a week after the voting took place. The institution with the most accurate prediction will become the most trusted institution because they succeeded in providing precise information and data. Consequently, this institution may be commended and be offered another project.

The above-mentioned facts show that economic interaction strongly depend on trust. If consumers trust is hurt, the risk will be immense and fatal. The decline of the trust could be seen from the case of Ajinomoto few year ago, a company that produces food flavoring. This brand is already well-known in Indonesia, but after the scandal was disclosed, the consumers trust began to fade. As a consequence, the 
company had to suffer immense loss. It all began with the announcement from Directorate General of Food and Drugs (POM) and MUI in December 2000 (Tempolnteraktif, Januari 5, 200I) that PT. Ajinomoto Indonesia was proven to intentionally replace polypeptonewithbactosoytonein the fermentation process of sugar cane molasses into Monosodium Glutamate so that they can reduce the production cost.

Actually, there is nothing wrong with replacing polypeptone with bactosoytone in the production process. The problem is, in the embedded theory, economic variables always go simultaneously with social variables. Bactosoytoneis bacterial development resulted from soybean enzyme mixed with porcine biocatalisator which is derived from the pigs pancreas. If this substitution process is used for the market outside Indonesia, it will not be a problem. But for Indonesian market, this becomes an immense problem, because the majority of Indonesian populations, which are notably the consumers of Ajinomoto, are Moslem. Islamic law (syariah) clearly stated that it is prohibited to consume anything that contains any part of pig. Any products are not openly declared their ingredients will be distrusted by Moslems.

Any producers who neglect social factor of certain consumers taste and belief will definitely suffer from immense loss. Even though this issue does not relate and affect consumers health directly, but the effect of this incident was astonishing. Ajinomoto had to withdraw its products from the market with almost 30 billion rupiahs in value. The aftermath was even worse; the consumers became reluctant to buy any products from Ajinomoto. At the same time, however, a rumor spread out in mass media that some housewares are made of melamine, a material that contains formalin that is hazardous to consumers' health. As a matter of fact, there are two kinds of melamine in the market. One is food grade melamine, the one that is safe to be used in feeding tools which is more expensive and the other has low quality and cheap. Nevertheless, this information does not necessarily stop people from buying the plates that contain cheap melamine. The sales of these house wares still could be found in traditional markets.

From the two cases above, we could consider that the existing trust in society is practiced by prevailing rationality in the society. Weber states that rationality was divided into value-oriented rationality and instrumental rationality. Value-oriented 
rationality is basically more complex and deeply rooted in culture (and religious belief) because it contains highest appreciation to the core values such as tradition, religious system and cultural norms. Meanwhile, instrumental rationality is more often urged by the development of common knowledge and understanding towards general issues.

In the second case, instrument rationality brings the awareness of society members on how to define organization systems, to build schools and factories as the tools they choose to achieve their purpose. Instrument rationality requires logic that the society members obtain from their knowledge. Thus, there would be increase or decrease in trust based on the occurring criticism in the society, if it happens to relatively well-informed society, the level of trust might drop, but if it happens to medium-informed society, the level of trust will not lessen because critical thinking does not arise here.Trust plays important and complex roles in daily operation of any economic institutions. The complexity of trust lies on the massive interaction of economy where there are many parties involved. If the level of trust is higher, the amount of investment and distribution will increase, and the more profit the company will get.

Understanding the business dynamics in the utilitarianism perspective (focusing on utility) shows that business as economic action always has two possibilities: gaining profit or suffering from loss. An individual who takes a role as an economic player is personified himself as a rational individual. The rational personification has a definition that an individual always considers utility aspect in every interaction and social relationship he establishes with other individuals. By doing so, an individual seems to always try to find the usefulness of an interaction and social transaction. Therefore, it is not surprising if an individual can use exploitative action as a rational instrument to avoid loss in social interaction and transaction.

In social transaction and economic interaction, the principle of utility is based on the rational calculation that makes the basic consideration in decision making; therefore it is not a surprise if business is dominated by the rational-calculative aspect. So, an individual who develops a business always asks himself about how much profit he will get from certain amount of money he invested.As in social interaction, economic interaction also supports some exploitative actions that make unpredictable 
situation, where loss and profit are inter-connected, so that an economic transaction at could make profit in one time, but it could bring loss at another time.

\section{CONCLUSION}

Trust is a social capital got through social processes which has big implication to economic transactions. Any business affairs and economic transaction are started from, with, and run by trust. The trust plays important role in running of business.Since fluctuation of price of any commodities and level of their selling product determined by the degree of consumers' trust. Lessons learned from the field teaches that the trust easy to be gone and hard to be re-treated. Whichever the tendency of the trust is, it directly influences up and down the value of transaction such as selling product.

The nature of having a balance in the transaction within the market mechanism is found in every form of exchange, the principle that always prevails and demands, more or less, an equal opportunity to get profit among the economic players in exchange. In this context, trust plays an important role in creating an in-favor situation and condition that encourages exchanges to open the possibility of making profits or experiencing loss for both sides. There is no doubt that implementation of trust is directed to three different aspects: trust in economic actor, in economic institution and its system, and in products. With these applications of trust will get benefit that transaction cost can be reduced, a business risk can be diminished and the economic actors will feel more secure.

\section{REFERENCES}

Auster, C. (1996). Sociology of Work,. California: Pine Grass Forga Press.

Chalid, P. (2004). Ekonomi Informal Pasca Jumatan dan Majelis Taklim. Laporan Penelitian. Jakarta: CSES.

Chalid, P.(2005). Sosiologi Ekonomi. Jakarta: CSES.

Chalid, P.(2012).Trust: Economic Capital and Social Transaction.Jakarta: CSES.

Chang, J.H.Y.et.al. (2016). Developing Trust in Close Personal Relationship: Ethnic Chinese's Experiences. Journal of Trust Research. Vol 6 (2), pp. 20I-2I 0.

Damsar.(1997). Sosiologi Ekonomi. Jakarta: RajaGrafindo Persada 
Dequech, D.(2003). Uncertainty and Economic Sociology: A Preliminary Discussion. Focus on Economic Sociology. American Journal of Economics and Sociology.

Furlong, D. (1996). Conceptualization of Trust in Economic Thought. New Jersey: Amazon.

Granoveter, M. \& R. Swedberg. (1992). The Sociology of Economic Life. Boulder: Westview Press

Li, Peter Ping, (20I4). Trust in Governance: A Micro-Macro Aproach. Jurnal of Trust Research. Vol 4 (2), pp. 19I-200.

Sayer, A.(2004). Market, Embedd edness and Trust: Problem of Polysemy and Idealism. Center for Researchon Innovation and Competition, University of Manchester

Smelser, N. J. (1976) The Sociology of Economic Life. New Jersey: Prentice Hall

Smelser, N.J\&R. Swedberg (ed). (1994), The Handbook of Economic Sociology. WestSussex: Princeton University Press.

Sirdesh mukh, D. (2002). Consumer Trust, Value and Loyalty in Relational Exchange. Journal of Marketing. Vol. 66 (I), Pp. 7I-80.. 